\title{
Improving Vegetative Growth of Aspidistra Elatiorl by Using Media and Fertilization
}

\author{
Mohamed, Safaa. M ${ }^{1}$; Ghatas, A.A. ${ }^{1}$; Mohamed, y.f1. Hamad, I.A ${ }^{1}$ \\ ${ }^{1}$ Horticulture, Dpt. Fac. Of Agri., Benha University.
}

\begin{abstract}
This experiment was carried out during two consecutive seasons of 2018/2019 in the experimental field of Fac. of Agriculture Moshtoher, Benha University to study the effect of media and fertilization on the growth (vegetative, roots and chemical constituents. The media content sand+ peat moss + compost Igave significant effect on No. of leaves, leaves area/plant, fresh and dry weight/plant, pedicel length/plant, N, P, K of leaves. The biggest fertilization gave the best results. The obtained results indicated that the combination between media (sand + peat moss +compost) with chemical fertilization at $6 \mathrm{~g} /$ pot gave high significant effect for all data recorded.
\end{abstract}

Keywords: Aspidistra elatior, fertilization, media

\section{Introduction}

Cast iron (Aspidistra elatiorL.) is a popular rhizomatous foliage plant belongs to the family Asparagaceae. It is native to Asia and commonly used as a house plant worldwide.

Cast iron is grown as a landscape plant in areas with dense shade and mild winters. It can be happily grown in both indoor and outdoor conditions and is tolerant to drought and wide range of soil types. It propagated by division of clumps at any time of the year - Aspidistra elatioris a local plant in Asparagaceae family that found in China, Japan and Northern Thailand. In Japanese also known as "Haran", an ornamental plant. It also used as folk medicine including antidiuretic and mucolytic agents. Previous studies found that this plant contained steroid compounds and had antifungal activity against Saccharomyces cerevisiae , Hansenulaanomala, Mucormucedo, and Candida albicans.Aspidistra elatioris the popular herbal tea due to its pharmacological activity. It has been used in the treatment of back pain, waist pain, aphthous ulcer, hypercholesterolemia and fatigue. Moreover, aspidistrin, its bioactive compound, also has antifungal effect against Saccharomyces cerevisiae, Mucormucedo and Candida albicans. SupawatcharaSinghatong (2017) growing media is one of the most important factors playing a key role in the quality production of flower and foliage plants. For optimum root and shoot growth, a potting medium should serve four major functions like nutrient supply, provision of water, gaseous exchange and physical support to plant. Different potting media can be utilized effectively to grow cast iron plants whereas the chemical and physical properties of growing media like $\mathrm{pH}$, electrical conductivity, texture, structure, particle density, consistency, organic matter contents, saturation percentage along with nitrogen, phosphorus and potassium are the crucial factors for optimum plant growth and development. Gamal (2018). The composition of a growing medium should be welldrained. Low insoluble salts, with an adequate exchange capacity. Since innumerable amendment combinations can produce a growing medium with these characteristics, it is important to consider the economic, cultural optimums, transportation, labor, and handling. It can be said that sand, clay, peat moss, perlite, vermiculite, and organic matter are the basic components of the special medium of planting (Hartmann et al., 2002). Peat moss is the most desirable organic matter for the preparation of growing media and is the most widely used substrate for potted plant production in nurseries and it accounts for a significant portion of the material used to grow potted plants (Ribeiroet al., 2007). Clay soils hold moisture and nutrients well and remain warm, in the autumn because they are slow to cool down. Mach of the water they contain will not be available to plants and in winter they are prone to waterlogging. (James and Michael, 2009). Fertilizing plants causes them to grow more rapidly and efficiently, just like ensuring a manufacturing plant has all the raw materials it needs for a production line. Lambers et al., 2000). The aim of the present work is the evaluate the influence of different soil media (Sand, Clay, (Sand+ peat moss), (Sand+ compost), (Sand+ peat moss+ compost) and fertilizer on growth and chemical composition of Aspidistra elatiorL plant.

\section{Material and Methods}

The present study was conducted during two successive seasons of 2017/2018 and 2018/2019 seasons at the Experimental Farm, of the Faculty Agriculture (Moshtoher), Benha University, Egypt. onAspidistra elatior

\section{A-Plant materials.}

The Aspidistra elatiorwere obtained from farm of Horticulture Department, Faculty of Agriculture, Benha University, Egypt. 
The plants were planting in plastic pots of $30 \mathrm{~cm}$ diameter (one plant / pot) packed with the five chosen growing media, mention later, and placed in a partial shade

B-Experimental procedure.

The Aspidistra elatiorplanted: on (4/1/2018) for the first season and (2018/1/2019) in the second The different five growing media chosen;

1- Sand

2- Clay

3- Sand+ peat moss $1: 1(\mathrm{v}: \mathrm{v})$

4- Sand+ compost 1:1 (v:v)

5- Sand+ peat moss+ compost 1:1 (v:v)

- The chemical fertilization at the rates of 0,4 and 6 g/pot were added monthly for (4) times throughout the growing season.
- The study contained 15 treatments (5 growing media $\mathrm{x} 3$ rates of chemical fertilization) with three replicates. Each replicate contained (9) pots.

- The treatment was conducted as follows:

- Sand + 0g N.P.K

- Sand + 4g N.P.K

- Sand + 6g N.P.K

- Clay + 0g N.P.K

- Clay +4 g N.P.K

- Clay +6 g N.P.K

- Sand+ peat moss +0 g N.P.K

- Sand+ peat moss $+4 \mathrm{~g}$ N.P.K

- Sand+ peat moss +6 g N.P.K

- Sand + compost +0 g N.P.K

- Sand + compost +4 g N.P.K

- Sand + compost +6 g N.P.K

- Sand + peat moss+ compost + 0g N.P.K

- Sand+ peat moss+ compost $+4 \mathrm{~g}$ N.P.K

- Sand+ peat moss+ compost +6 g N.P.K

Table 1. a. The mean chemical characteristics of chosen growing media before planting

\begin{tabular}{lllllll}
\hline Media & PH & $(\mathrm{Ec}) \mathrm{ds} / \mathrm{m}$ & $\mathrm{N}(\%)$ & $\mathrm{P}(\%)$ & $\mathrm{K}(\mathrm{ppm})$ & Organic matter (\%) \\
\hline Clay & $\mathbf{7 . 9 6}$ & $\mathbf{0 . 3 7 6 9}$ & $\mathbf{3 . 9 1}$ & $\mathbf{0 . 1 1}$ & $\mathbf{3 8 6 6 2 . 1 9}$ & $\mathbf{1 4 . 8}$ \\
Peat moss & $\mathbf{2 . 8 2}$ & $\mathbf{0 . 1 2 0 2}$ & $\mathbf{3 . 7 7}$ & $\mathbf{0 . 1 1}$ & $\mathbf{3 5 9 8 . 1 0}$ & $\mathbf{9 8 . 5}$ \\
Compost & $\mathbf{8 . 3 3}$ & $\mathbf{2 . 1 1 6}$ & $\mathbf{2 . 2 3}$ & $\mathbf{0 . 0 2}$ & $\mathbf{1 3 4 1 . 0 6}$ & $\mathbf{1 1 . 8}$ \\
Sand+peat moss & $\mathbf{5 . 9}$ & $\mathbf{1 . 1 7 1}$ & $\mathbf{3 . 2 2}$ & $\mathbf{0 . 1 3}$ & $\mathbf{2 4 5 2 . 2 2}$ & $\mathbf{2 1}$ \\
Sand+compost & $\mathbf{8 . 1 8}$ & $\mathbf{1 . 2 7 7}$ & $\mathbf{2 . 0 9}$ & $\mathbf{0 . 0 3}$ & $\mathbf{1 4 5 4 . 5 5}$ & $\mathbf{8 . 6}$ \\
Sand+peatmoss+compost & $\mathbf{7 . 2 6}$ & $\mathbf{1 . 4 2 1}$ & $\mathbf{1 . 8 1}$ & $\mathbf{0 . 0 6}$ & $\mathbf{2 1 8 1 . 8 3}$ & $\mathbf{1 0 . 4}$ \\
\hline
\end{tabular}

Table 2. a. The mean chemical characteristics of chosen growing media after planting

\begin{tabular}{|c|c|c|c|c|c|c|c|}
\hline Media & $\mathbf{P H}$ & (Ec)ds/m & $\mathbf{N}(\%)$ & $\mathbf{P}(\%)$ & $\mathbf{K}(\mathbf{p p m})$ & $\begin{array}{l}\text { Organic } \\
(\%)\end{array}$ & matter \\
\hline Sand (4gm) & 6.82 & 0.2272 & 0.22 & 0.011 & 47943 & 7.3 & \\
\hline Sand (6gm) & 7.36 & 0.1534 & 0.244 & 0.19 & 515.32 & 2.5 & \\
\hline Clay (4gm) & 7.95 & 1.214 & 0.41 & 0.20 & 3562.54 & 28.5 & \\
\hline Clay (6gm) & 7.91 & 1.202 & 0.48 & 0.15 & 3697.67 & 31.6 & \\
\hline Sand+peatmoss (4gm) & 4.56 & 0.8013 & 0.33 & 0.11 & 469.94 & 31.6 & \\
\hline Sand+peat moss (6gm) & 4.62 & 0.16385 & 0.39 & 0.08 & 1682.54 & 20.5 & \\
\hline Sand+ compost (4gm) & 7.20 & 0.5246 & 0.45 & 0.05 & 1913.96 & 9.8 & \\
\hline Sand+ compost (6gm) & 6.92 & 0.7011 & 0.44 & 0.09 & 855.62 & 10.1 & \\
\hline Sand+ peat moss+ compost $(4 \mathrm{gm})$ & 4.75 & 0.1916 & 0.27 & 0.15 & 684.22 & 38.5 & \\
\hline Sand+ peat moss+ compost $(6 \mathrm{gm})$ & 5.46 & 0.8075 & 0.52 & 0.01 & 522.45 & 26.4 & \\
\hline
\end{tabular}

Data recorded:

On vegetative growth:

Vegetative growth parameters were measured at the end of each season, the recorded data included:

1- Number of leaves/ plants

2- Fresh weight of leaves ( $\mathrm{g})$.

3- Dry weight of leaves (g).

4- Leaf area $(\mathrm{cm} 2)$.

\section{Root growth parameters}

1- Number of roots / plants

2- Length of root /plant $(\mathrm{cm})$

3- Fresh weight of roots/plant (g)

4- Dry weight of roots /plant(g)

Chemical composition:

1- Chlorophyll (a and b) contents, (mg/g FW).

2 - Nitrogen content in leaves (\% DW).
3- Phosphorus content in leaves (\% DW).

Potassium content in leaves (\% DW).

- N\% was determined by method as described by Horneck and Miller (1998).

- P\% was determined by method as described by Hucker and Catroux (1980).

- $\mathrm{K} \%$ was determined by method as described by Horneck and Hanson (1998).

- The photosynthetic pigments chlorophyll a, b was extracted by methanol alcohol according to Moron (1982) using the spectrophotometer at wavelength of $656,665 \mathrm{~nm}$, respectively.

- Statistical analysis:

- All obtained data in both seasons of study were subjected to analysis of variance as factorial experiments in a complete randomized block design. 
L.S.D. method was used to differentiate between means according to Snedecor and Cochran (1989).

Results
- Effect of some growing media and chemical fertilization on some growth parameters of Aspidistra elatior. plants

I- Vegetative growth parameters

Table 3. Effect of growing media and chemical fertilization on plant height of Aspidistra elatiorduring 2018 and 2019 seasons

\begin{tabular}{|c|c|c|c|c|c|c|c|c|}
\hline \multirow{2}{*}{$\begin{array}{l}\begin{array}{l}\text { Parameters } \\
\text { treatment }\end{array} \\
\text { chemical fertilizer }\end{array}$} & \multicolumn{4}{|c|}{ Plant height $(\mathrm{cm})$} & & \multicolumn{3}{|c|}{ Plant height $(\mathrm{cm})$} \\
\hline & \multicolumn{8}{|c|}{ chemical fertilizer } \\
\hline 1st season & \multicolumn{8}{|c|}{ 2nd season } \\
\hline 0g/pot & 4g/pot & & 6g/pot & Mean & 4g/pot & 6g/pot & & Mean \\
\hline Sand & 26.56 & 33.25 & 46.22 & 35.34 & 425.66 & 34.22 & 43.99 & 34.62 \\
\hline Clay & 35.55 & 45.31 & $\mathbf{5 7 . 2 5}$ & 46.03 & 35.26 & 46.35 & 58.06 & 46.55 \\
\hline Sand+peat moss & 38.12 & 47.68 & 60.01 & 48.60 & $0 \quad 38.69$ & 46.65 & 62.36 & 49.23 \\
\hline Sand+ compost & 30.55 & 36.22 & 45.02 & 37.26 & $6 \quad 29.55$ & 38.04 & 44.66 & 37.41 \\
\hline Sand+peatmoss+compost & 38.22 & 50.25 & 62.33 & 50.02 & $2 \quad 40.22$ & 51.55 & 61.36 & 51.04 \\
\hline Mean & \multicolumn{2}{|c|}{33.80} & 42.54 & 54.16 & 33.87 & 43.36 & \multicolumn{2}{|c|}{54.08} \\
\hline L.S.D. at 0.05 for & & & $\begin{array}{l}\text { Fertiliz } \\
\text { interac }\end{array}$ & $\begin{array}{l}\text { ation= } 1.37 \\
\text { ion=3.12 }\end{array}$ & $7 \quad$ Media $=1.54$ & $\begin{array}{l}\text { Fertiliz } \\
\text { Media= } \\
\text { interac }\end{array}$ & $\begin{array}{l}\text { tion }= \\
\text { on }=3.0\end{array}$ & $\begin{array}{l}1.38 \\
1.55\end{array}$ \\
\hline
\end{tabular}

Table 4. Effect of growing media and chemical fertilization on number of leaves/plant of Aspidistra elatiorduring 2018 and 2019 seasons.

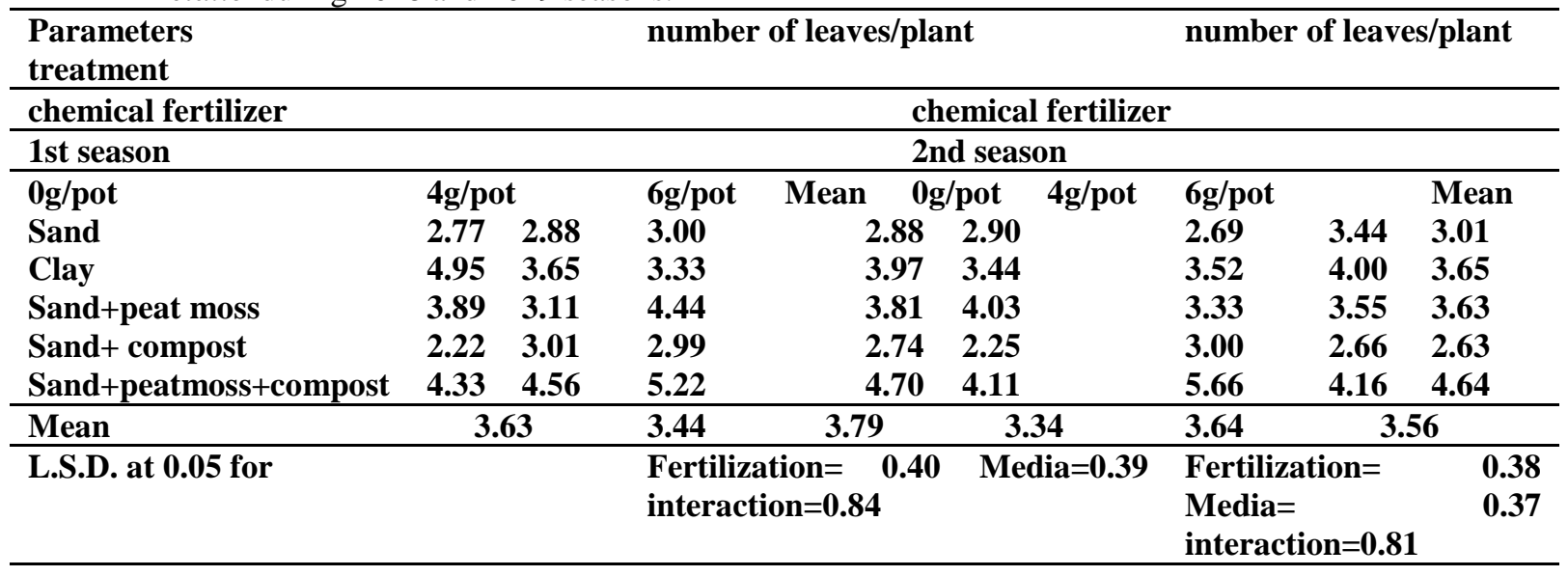

Table 5. Effect of growing media and chemical fertilization on leaf blade width $(\mathrm{cm})$ of Aspidistra elatiorduring 2018 and 2019 seasons.

\begin{tabular}{|c|c|c|c|c|c|c|c|c|}
\hline \multirow{2}{*}{$\begin{array}{l}\text { Parameters } \\
\text { treatment } \\
\text { chemical fertilizer } \\
\end{array}$} & \multicolumn{5}{|c|}{ Leaf Blade Width(cm) } & \multicolumn{3}{|c|}{ Leaf Blade Width(cm) } \\
\hline & \multicolumn{8}{|c|}{ chemical fertilizer } \\
\hline 1st season & \multicolumn{8}{|c|}{ 2nd season } \\
\hline 0g/pot & 4g/pot & & 6g/pot & Mean & 0g/pot $\quad 4 g / p o t$ & 6g/pot & & Mean \\
\hline Sand & 16.01 & 18.22 & 20.56 & 18.22 & $2 \quad 17.14$ & 19.25 & 22.35 & 19.58 \\
\hline Clay & 17.32 & 19.60 & 22.93 & 19.95 & $5 \quad 18.98$ & 21.67 & 24.65 & 21.76 \\
\hline Sand+peat moss & 20.32 & 23.54 & 26.35 & 23.40 & 21.54 & 23.89 & 27.97 & 24.46 \\
\hline Sand+ compost & 17.10 & 19.20 & 20.14 & 18.81 & $1 \quad 17.48$ & 19.68 & 21.12 & 19.42 \\
\hline Sand+peatmoss+compost & 23.25 & 25.45 & 28.95 & 25.88 & $8 \quad 25.64$ & 28.31 & 30.31 & 28.08 \\
\hline Mean & \multicolumn{2}{|c|}{18.80} & 21.02 & 23.78 & 20.15 & 22.56 & \multicolumn{2}{|c|}{25.28} \\
\hline L.S.D. at 0.05 for & & & $\begin{array}{l}\text { Fertiliz } \\
\text { interac }\end{array}$ & $\begin{array}{l}\text { tion }=0.66 \\
\text { on }=1.51\end{array}$ & Media $=0.75$ & $\begin{array}{l}\text { Fertiliz } \\
\text { Media: } \\
\text { interac }\end{array}$ & $\begin{array}{l}\text { tion }= \\
\text { on=01. }\end{array}$ & $\begin{array}{l}0.71 \\
0.80\end{array}$ \\
\hline
\end{tabular}


Table 6. Effect of growing media and chemical fertilization on Leaf area/plant(cm2)of Aspidistra elatiorduring 2018 and 2019 seasons.

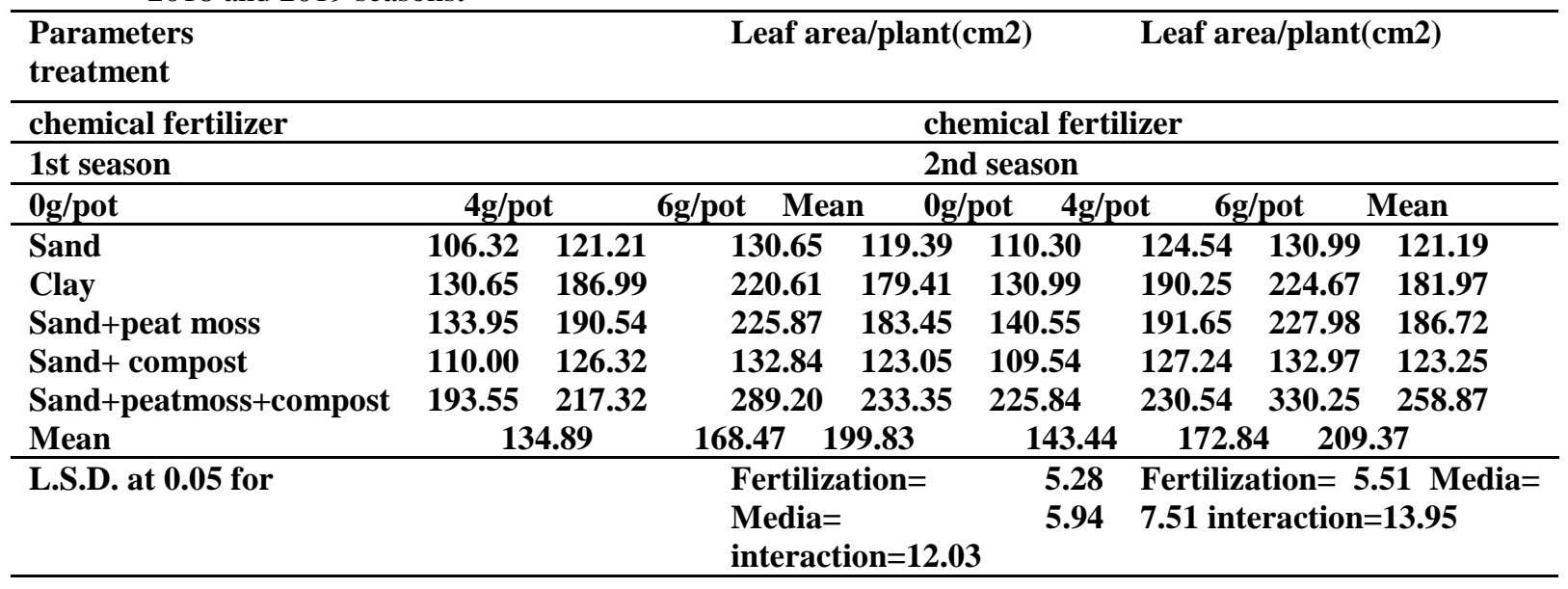

Table 7. Effect of growing media and chemical fertilization on fresh weight of leaves (g) of Aspidistra elatiorduring 2018 and 2019seasons.

\begin{tabular}{|c|c|c|c|c|c|c|c|}
\hline \multirow{2}{*}{$\begin{array}{l}\text { Parameters } \\
\text { treatment } \\
\text { chemical fertilizer }\end{array}$} & \multicolumn{4}{|c|}{ fresh weight of leaves (g) } & \multicolumn{3}{|c|}{ fresh weight of leaves (g) } \\
\hline & \multicolumn{7}{|c|}{ chemical fertilizer } \\
\hline 1st season & \multicolumn{7}{|c|}{ 2nd season } \\
\hline 0g/pot & 4g/pot & 6g/pot & Mean & gg/pot $\quad 4 g / p o t$ & 6g/pot & & Mean \\
\hline Sand & $33.25 \quad 39.45$ & 41.33 & 38.01 & 131.88 & 34.33 & 38.66 & 34.95 \\
\hline Clay & $37.44 \quad 42.05$ & $\mathbf{5 0}$ & 43.16 & $6 \quad 46.77$ & 46.77 & 40.33 & 44.62 \\
\hline Sand+peat moss & $42.11 \quad 39.55$ & 45.22 & 42.29 & $9 \quad 45.66$ & 39.22 & 40.66 & 41.84 \\
\hline Sand+ compost & $28.66 \quad 34.25$ & 36 & 32.97 & $7 \quad 27.44$ & 33.05 & 37.66 & 32.71 \\
\hline Sand+peatmoss+compost & $52.88 \quad 47.44$ & 50.77 & 50.36 & $6 \quad 50.88$ & 54.11 & 46.77 & 50.58 \\
\hline Mean & 38.86 & 40.54 & 44.66 & 40.25 & 41.49 & \multicolumn{2}{|c|}{40.81} \\
\hline L.S.D. at 0.05 for & & $\begin{array}{l}\text { Fertiliz } \\
\text { interac }\end{array}$ & $\begin{array}{l}\text { tion }=1.30 \\
\text { on }=3.34\end{array}$ & Media= 1.82 & $\begin{array}{l}\text { Fertiliz } \\
\text { Media= } \\
\text { interac }\end{array}$ & $\begin{array}{l}\text { tion }= \\
\text { on }=2.8\end{array}$ & $\begin{array}{l}1.24 \\
1.45\end{array}$ \\
\hline
\end{tabular}

Table 8. Effect of growing media and chemical fertilization on Dry weight of leaves/plant/ (g).of Aspidistra elatiorduring 2018 and 2019 seasons.

\begin{tabular}{|c|c|c|c|c|c|c|c|c|c|}
\hline \multicolumn{3}{|l|}{ Parameters treatment } & \multicolumn{4}{|c|}{ Dry weight of leaves/plant/ (g). } & \multicolumn{3}{|c|}{$\begin{array}{l}\text { Dry weight of } \\
\text { leaves/plant/ (g). }\end{array}$} \\
\hline \multirow{2}{*}{\multicolumn{3}{|c|}{$\begin{array}{l}\text { chemical fertilizer } \\
\text { 1st season }\end{array}$}} & \multicolumn{4}{|c|}{ chemical fertilizer } & \multirow[b]{3}{*}{$6 \mathrm{~g} / \mathrm{pot}$} & \multirow[b]{4}{*}{17.88} & \multirow[b]{3}{*}{ Mean } \\
\hline & & & & & 2nd se: & & & & \\
\hline 0g/pot & 4g/pot & & 6g/pot & Mean & 0g/pot & 4g/pot & & & \\
\hline Sand & 15.50 & 16.55 & 17.20 & & 16.41 & 15.90 & 17.00 & & 16.92 \\
\hline Clay & 16.00 & 16.13 & 17.65 & & 16.59 & 16.02 & 17.00 & 18.03 & 17.01 \\
\hline Sand+ peat moss & 17.20 & 18.00 & 19.06 & & 18.08 & 18.32 & 20.04 & 21.25 & 19.87 \\
\hline Sand+ compost & 15.95 & 16.03 & 17.88 & & 16.62 & 16.10 & 16.99 & 18.09 & 17.06 \\
\hline Sand+peatmoss+compost & 19.29 & 21.66 & 24.00 & & 21.65 & 21.00 & 24.30 & 26.89 & 24.06 \\
\hline Mean & \multicolumn{2}{|c|}{16.78} & 17.67 & \multicolumn{2}{|c|}{19.15} & 17.46 & 19.06 & \multicolumn{2}{|c|}{20.40} \\
\hline L.S.D. at 0.05 for & & & $\begin{array}{l}\text { Fertili } \\
\text { interac }\end{array}$ & $\begin{array}{l}\text { ation= } \\
\text { ion }=1.4\end{array}$ & $0.68 \quad \mathrm{~N}$ & $=0.63$ & $\begin{array}{l}\text { Fertili } \\
\text { Media } \\
\text { intera }\end{array}$ & $\begin{array}{l}\text { tion }=0 \\
0.67 \\
\text { ion }=1.3\end{array}$ & \\
\hline
\end{tabular}

Our results about the effect of some growing media and chemical fertilization on Vegetative growth parameters are in harmony with Mohamed (2018) growing Dypsiscabadae palm plants in a medium contained compost + peat moss + perlite or a medium composed of clay + sand + compost + peat moss +perlite and supplemented with kristalon fertilizer at $8 \mathrm{~g} /$ pot produced the best growth and quality of this plant.

And Ashour (2008) found that addition of clay or composted sewage sludge as soil amendments, to the sandy soil had favorable effect on the vegetative characteristics of Plumbagocapensisplants (in most cases), as compared to plants grown. Clay was the most 
effective soil amendment for promoting vegetative characteristics giving the highest mean values for plant height, stem diameter, fresh and dry weights of leaves, number of branches/ plants, leaf area, fresh and dry weights of stems and roots/plant, and root length.
Haidar (2010) found that growing Dracaena marginata"Bicolor" in a pea tmoss medium increased plant height, number of leaves, leaf area, fresh weight of leaves and stems, and dry weight of leaves. While, growing plants in a mixture of sand + peat moss significantly increased stem diameter and dry weight of stem. II- Root growth parameters

Table 9. Effect of growing media and chemical fertilization on Number of roots / plant of Aspidistra elatiorduring 2018 and 2019seasons.

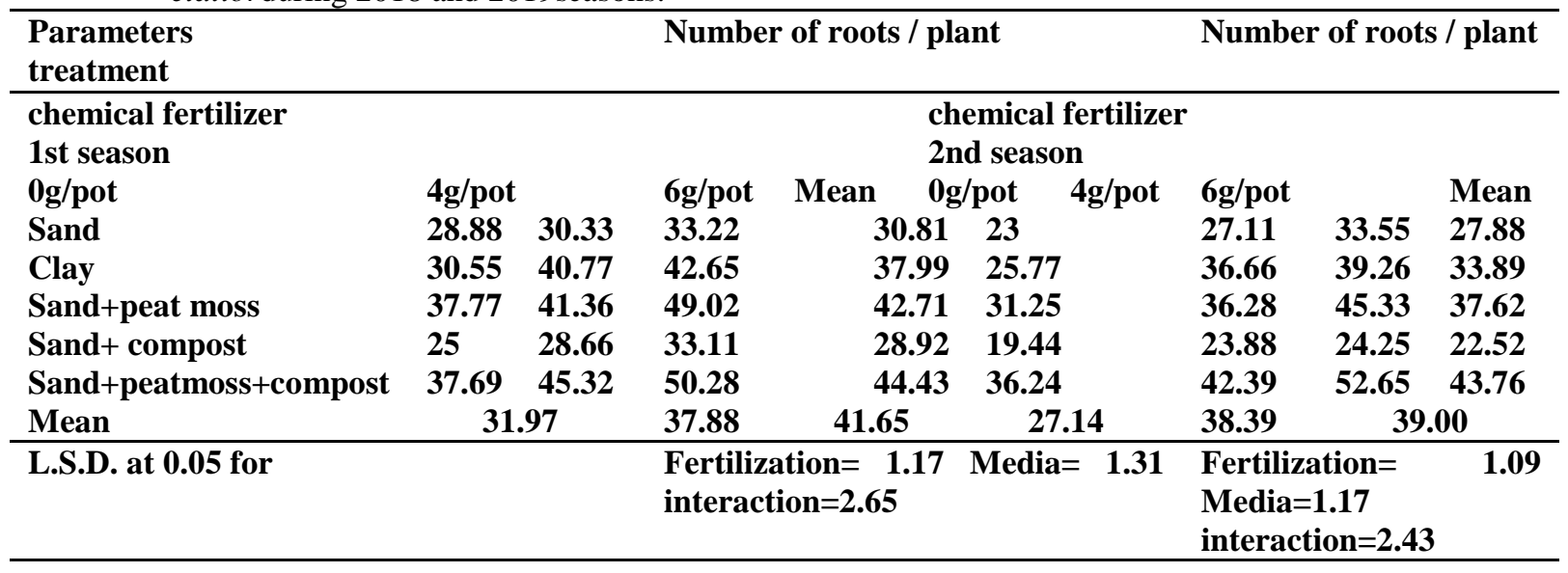

Table10. Effect of growing media and chemical fertilization on length of roots /plant (cm) of Aspidistra elatiorduring 2018 and 2019seasons.

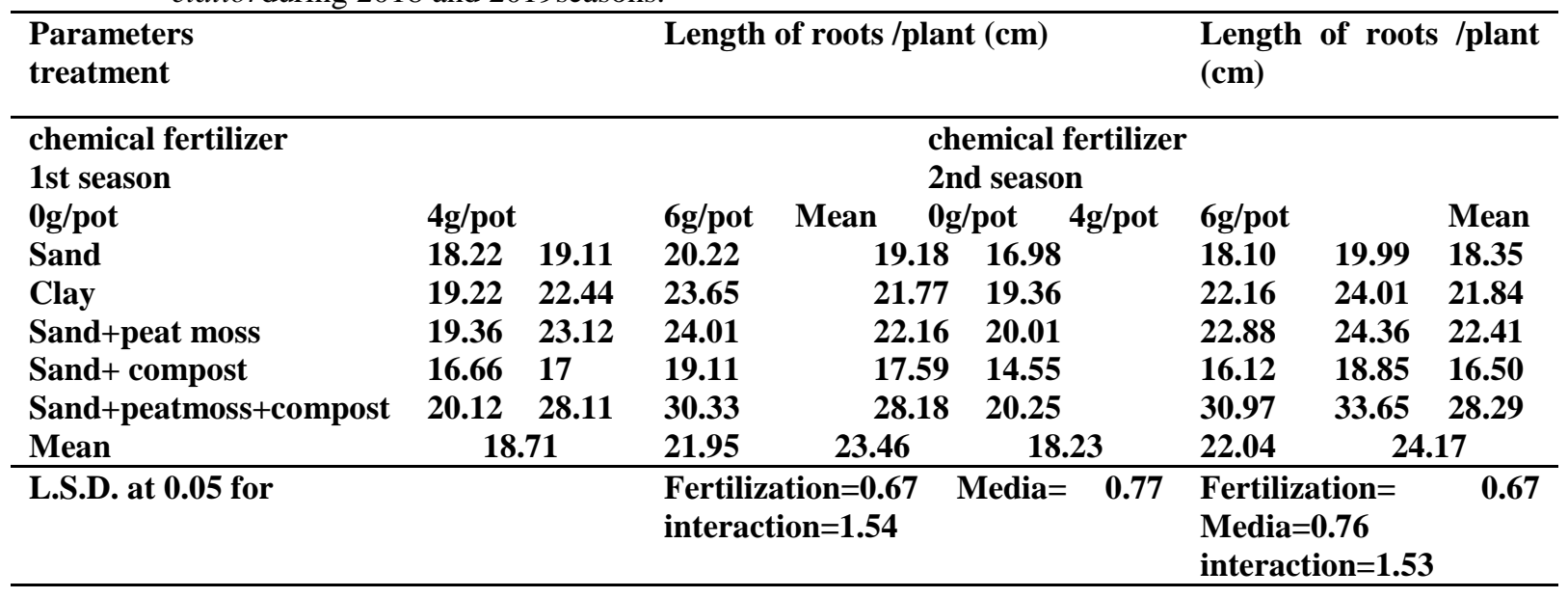

Table 11. Effect of growing media and chemical fertilization on Fresh weight of roots / plant (g) of Aspidistra elatiorduring 2018 and 2019seasons.

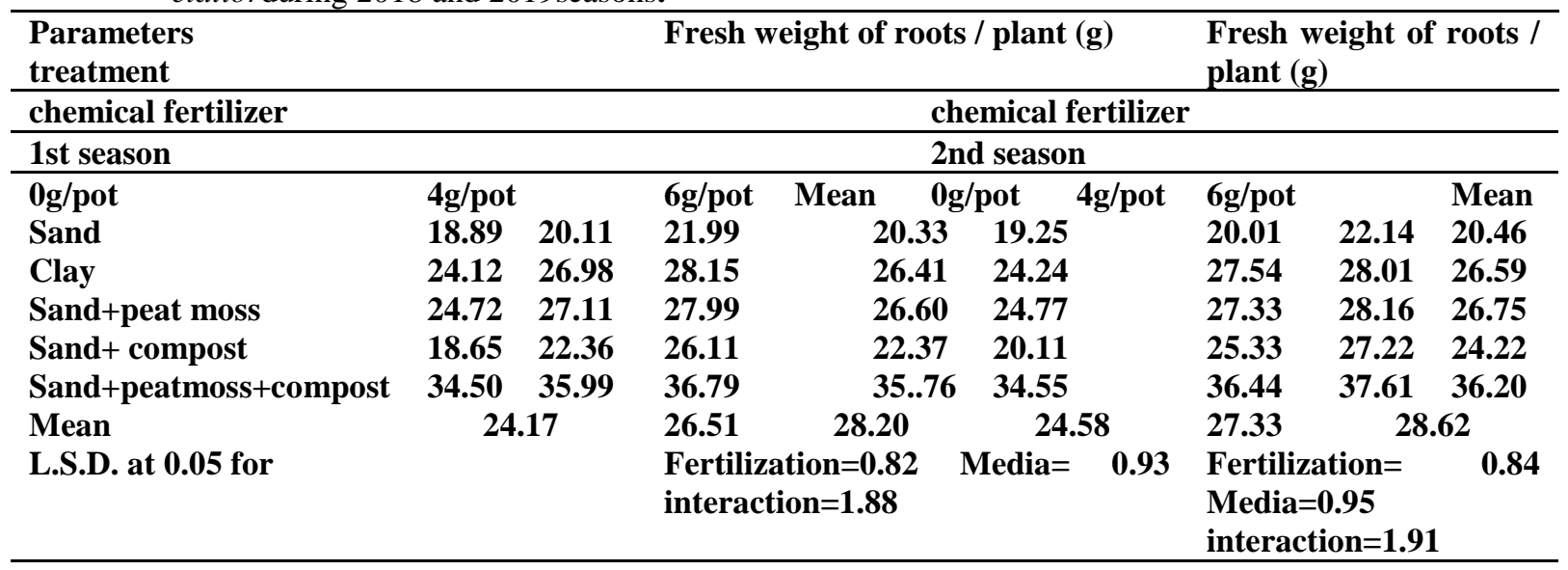


Table 12. Effect of growing media and chemical fertilization on dry weight of roots / plant (g)ofAspidistra elatiorduring 2018 and 2019seasons.

\begin{tabular}{|c|c|c|c|c|c|c|c|}
\hline \multicolumn{2}{|l|}{$\begin{array}{l}\text { Parameters } \\
\text { treatment }\end{array}$} & \multicolumn{3}{|c|}{ Dry weight of roots / plant (g } & \multicolumn{3}{|c|}{$\begin{array}{l}\text { Dry weight of roots / } \\
\text { plant (g }\end{array}$} \\
\hline chemical fertilizer & \multicolumn{7}{|c|}{ chemical fertilizer } \\
\hline 1st season & & & & nd season & & & \\
\hline 0g/pot & 4g/pot & 6g/pot & Mean & g/pot $4 \mathrm{~g} /$ pot & 6g/pot & & Mean \\
\hline Sand & 5.01 & 6.69 & 5.73 & 5.35 & 6.01 & 7.00 & 6.12 \\
\hline Clay & 7.03 & 13.33 & 10.08 & $\begin{array}{ll}3 & 7.34\end{array}$ & 10.65 & 13.92 & 10.63 \\
\hline Sand+peat moss & 12.87 & 14.66 & 11.85 & $5 \quad 8.82$ & 13.12 & 15.03 & 12.32 \\
\hline Sand+ compost & 6.54 & 9.02 & 7.59 & 6.98 & 8.02 & 9.11 & 8.03 \\
\hline Sand+peatmoss+compost & $10.78 \quad 14.67$ & 16.66 & 14.03 & $3 \quad 11.57$ & 15.64 & 18.01 & 15.07 \\
\hline Mean & 7.47 & 10.03 & 12.07 & 8.01 & 10.68 & \multicolumn{2}{|c|}{12.61} \\
\hline L.S.D. at 0.05 for & & $\begin{array}{l}\text { Fertiliz } \\
\text { interac }\end{array}$ & $\begin{array}{l}\text { tion }=0.31 \\
\text { ton }=0.69\end{array}$ & Media $=0.34$ & $\begin{array}{l}\text { Fertiliz } \\
\text { Media= } \\
\text { interac }\end{array}$ & $\begin{array}{l}\text { tion }=0 \\
.36 \\
\text { on }=0.7\end{array}$ & \\
\hline
\end{tabular}

These results are similar with those reported by Olosunde et al ., (2017) in Dieffenbachia amoenaplants showed that using media containing rice husk gave the best result vegetative growth, colour ranking, dry matter and root growth. And Hegazey (2014) showed that using rooting media containing sand + clay + peatmoss + perlite $(\mathrm{v}: \mathrm{v})$ increased rooting percentage and the number of roots/cutting as well as their fresh and dry weights of Conocarpus erectus cuttings. Also, seedling vegetative growth i.e., plant height, leaves number, fresh and dry weights of leaves were increased as compared with control (clay+sand).

III- Chemical composition determination:

Table 13. Effect of growing media and chemical fertilization on leaf nitrogen percentage of Aspidistra elatiorduring 2018 and 2019seasons.

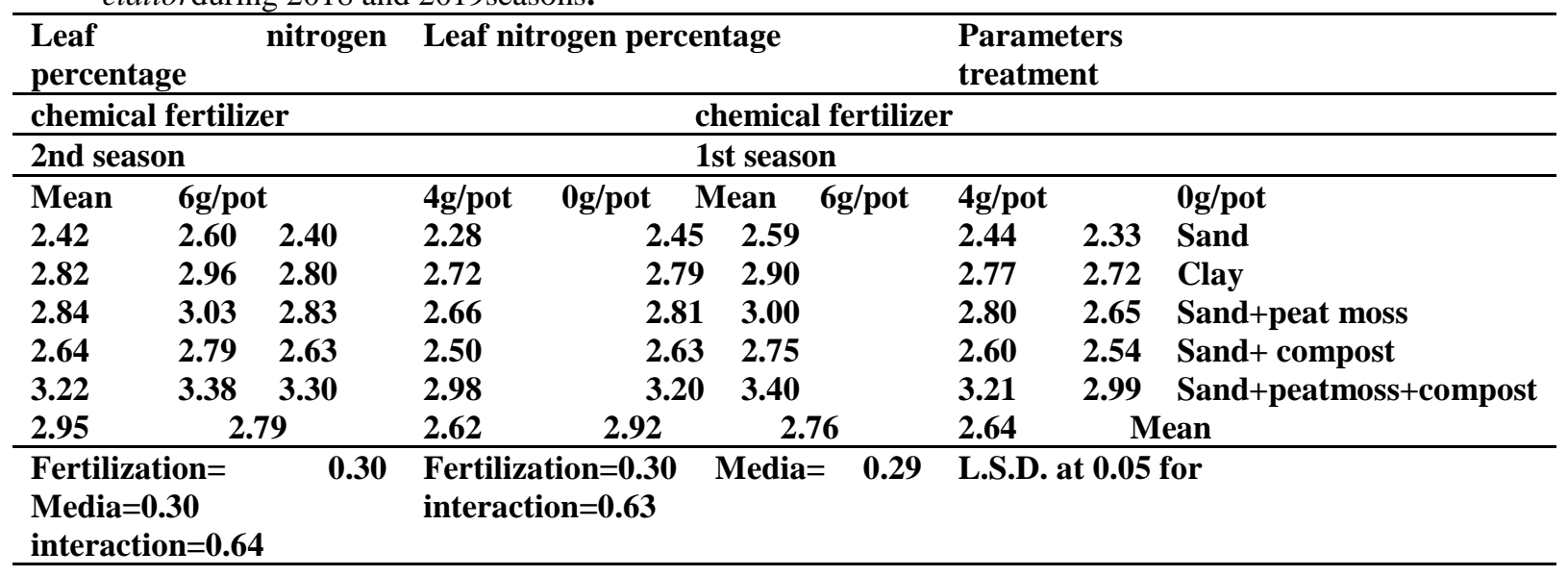

Table 14. Effect of growing media and chemical fertilization on leaf phosphorus percentage of Aspidistra elatiorduring 2018 and 2019seasons.

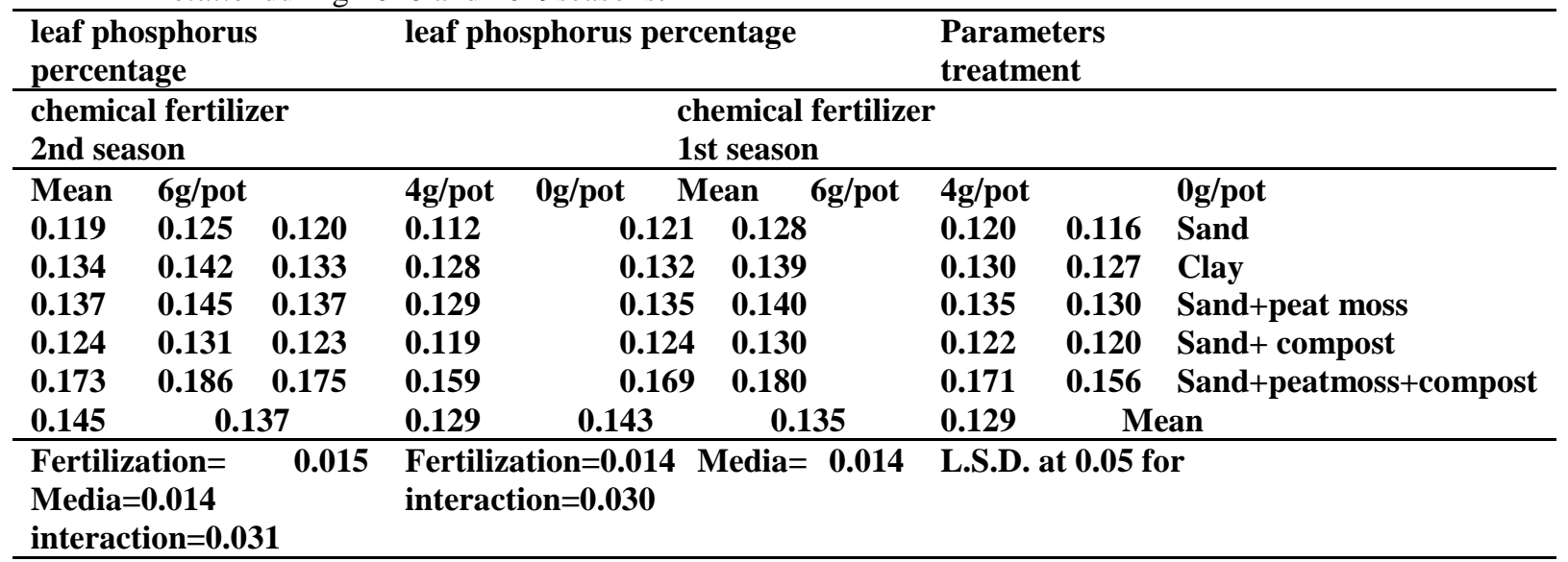


Table 15. Effect of growing media and chemical fertilization on leaf potassium percentage of Aspidistra elatiorduring 2018 and 2019 seasons.

\begin{tabular}{|c|c|c|c|c|c|c|c|c|}
\hline \multicolumn{3}{|c|}{$\begin{array}{l}\text { leaf potassium } \\
\text { percentage }\end{array}$} & \multicolumn{3}{|c|}{ leaf potassium percentage } & \multicolumn{3}{|c|}{$\begin{array}{l}\text { Parameters } \\
\text { treatment }\end{array}$} \\
\hline \multicolumn{3}{|c|}{ chemical fertilizer } & \multicolumn{6}{|c|}{ chemical fertilizer } \\
\hline \multicolumn{3}{|c|}{ 2nd season } & \multicolumn{3}{|c|}{ 1st season } & & & \\
\hline Mean & 6g/pc & & 4g/pot & Mean & 6g/pot & 4g/pot & & 0g/pot \\
\hline 1.23 & 1.30 & 1.23 & 1.18 & 1.29 & & 1.21 & 1.15 & Sand \\
\hline 1.39 & 1.46 & 1.40 & 1.31 & 1.43 & & 1.39 & 1.30 & Clay \\
\hline 1.41 & 1.48 & 1.42 & 1.34 & 1.47 & & 1.40 & 1.34 & Sand+peat moss \\
\hline 1.29 & 1.36 & 1.30 & 1.23 & 1.32 & & 1.29 & 1.20 & Sand+ compost \\
\hline 1.49 & 1.58 & 1.49 & 1.40 & 1.54 & & 1.45 & 1.38 & Sand+peatmoss+compost \\
\hline 1.43 & \multicolumn{2}{|c|}{1.36} & 1.41 & \multicolumn{2}{|c|}{1.34} & \multicolumn{3}{|c|}{$1.27 \quad$ Mean } \\
\hline \multicolumn{3}{|c|}{$\begin{array}{l}\text { Fertilization }= \\
\text { Media }=0.14 \\
\text { interaction }=0.31\end{array}$} & $\begin{array}{l}\text { Fertilization }=0.14 \\
\text { interaction }=0.30\end{array}$ & Media= & 0.14 & L.S.D. & t 0.05 & for \\
\hline
\end{tabular}

Table 16 . Effect of growing media and chemical fertilization on leaf total carbohydrates percentage of Aspidistra elatiorduring 2018 and 2019 seasons.

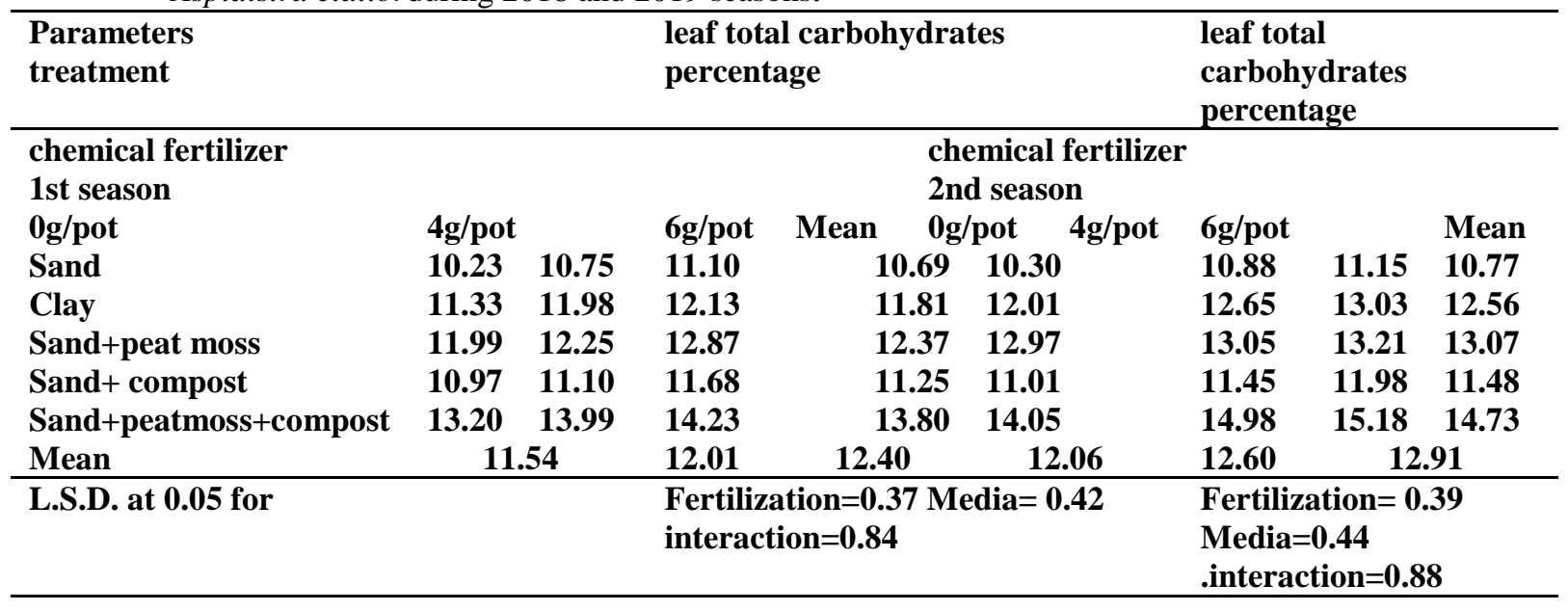

Table 17. Effect of growing media and chemical fertilization on leaf Chlorophyll a (mg/g F.W) (mg / 100gf.w) of Aspidistra elatiorduring 2018 and 2019

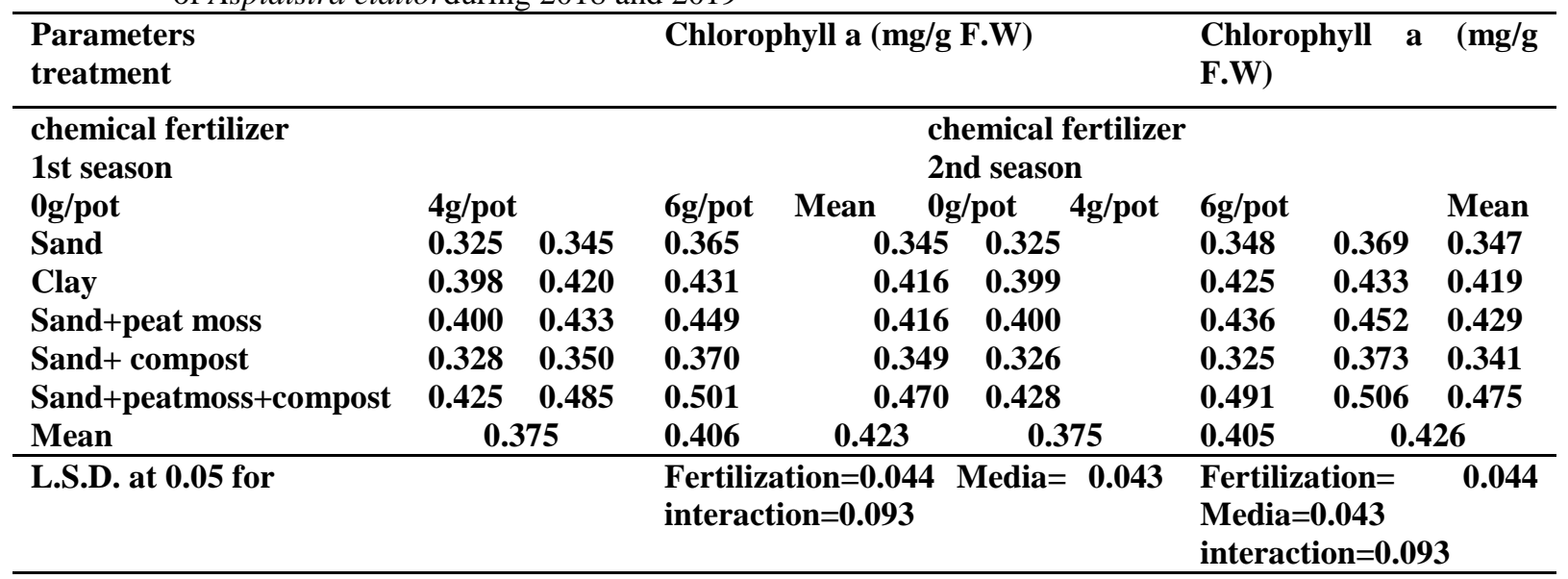


Table18. Effect of growing media and chemical fertilization on leaf Chlorophyll b (mg/g F.W) (mg / 100gf.w)ofAspidistra elatiorduring 2018 and 2019

\begin{tabular}{|c|c|c|c|c|c|c|c|c|c|}
\hline \multirow{2}{*}{$\begin{array}{l}\begin{array}{l}\text { Parameters } \\
\text { treatment }\end{array} \\
\text { chemical fertilizer } \\
\end{array}$} & & \multicolumn{5}{|c|}{ Chlorophyll b (mg/g F.W) } & \multicolumn{2}{|c|}{$\begin{array}{l}\text { Chlorophyll b } \\
\text { F.W) }\end{array}$} & $(\mathrm{mg} / \mathrm{g}$ \\
\hline & & \multicolumn{8}{|c|}{ chemical fertilizer } \\
\hline 1st season & \multicolumn{9}{|c|}{ 2nd season } \\
\hline 0g/pot & 4g/pot & & 6g/pot & Mean & 0g/pot & 4g/pot & 6g/pot & & Mean \\
\hline Sand & 0.210 & 0.215 & 0.218 & 0.214 & 40.212 & & 0.220 & 0.226 & 0.219 \\
\hline Clay & 0.298 & 0.300 & 0.310 & 0.302 & $2 \quad 0.300$ & & 0.310 & 0.318 & 0.309 \\
\hline Sand+peat moss & 0.325 & 0.330 & 0.339 & 0.331 & $1 \quad 0.330$ & & 0.339 & 0.345 & 0.338 \\
\hline Sand + compost & 0.300 & 0.310 & 0.319 & 0.309 & 0.315 & & 0.317 & 0.328 & 0.320 \\
\hline Sand+peatmoss+compost & 0.379 & 0.400 & 0.415 & 0.398 & 0.400 & & 0.418 & 0.429 & 0.415 \\
\hline Mean & 0.302 & & 0.311 & 0.320 & 0.3 & 311 & 0.320 & 0.3 & \\
\hline L.S.D. at 0.05 for & & & $\begin{array}{l}\text { Fertiliz } \\
\text { interac }\end{array}$ & $\begin{array}{l}\text { tion }=0.034 \\
\text { on }=0.072\end{array}$ & Media= & $=\mathbf{0 . 0 3 3}$ & $\begin{array}{l}\text { Fertili } \\
\text { Media } \\
\text { intera }\end{array}$ & $\begin{array}{l}\operatorname{tion}= \\
.034 \\
\text { on }=0.0\end{array}$ & 0.35 \\
\hline
\end{tabular}

Salehi (2013) reported that growing SpathiphyllumwallisiiRegel plants in a mixture medium containing compost, peat moss and sand induced the best growth and chemical constituents of this plant.

Mazheret al. (2010) on JatrophacurcaL. showed that clay medium tended to increase chlorophyll a, b, $\mathrm{a}+\mathrm{b}$ and carotenoids as well as minerals content of $\mathrm{N}, \mathrm{P}$ and $\mathrm{K}$ in fresh leaves as comparing with the sandy and mixing media. Haidar (2010) on Dracaena marginata"Bicolor" found that peatmoss medium increased the $\mathrm{N}, \mathrm{K}, \mathrm{Fe}, \mathrm{Zn}$ and $\mathrm{Mn} \%$ in the leaves and stem. While, the mixture of sand + peat moss increased $\mathrm{P} \%$ in the leaves, whereas peat moss medium increased $\mathrm{P} \%$ in stem.

\section{Discussion}

The present experiment was conducted to examine the response of Aspidistra elatiorto different mixture media and chemical fertilization as well as their combination on growth and chemical composition Obtained results of this experiment were presented in the previous part and this results could be physiologically explained and discussed as follow:-

\section{A- Effect of media:}

Obtained data proved that vegetative growth characters (tables 3,4,5,6,7 and 8) root growth parameters table $(9,10,11$, and 12) and chemical composition $(13,14,15,16$ and17) of Aspidistra elatiorwere increased by different growing media, especially using sand+ peat moss+ compost.

Many investigations explained the role of growing media:

MehboobAlamet al.,(2019) reported that The term growing media is amongst other used to describe the material used in a container to grow a plant. Various growing media are available including peat moss, spent mushroom compost etc. Peat moss is dried sphagnum moss that has the capacity to gained and release nutrients and moisture to the growing media.
And Mehmood TM et al., (2013) reported that peat moss media comprised of important elements due to which elongation of cell and rapid division of cell takes place. As a result, thickness of the stem occurs. Stem with thickest diameter are stronger and show resistance against different abiotic stresses.

The stem thickness of cutting plays a vital role in enhancing the water and nutrients transportation. It was reported that peat moss medium increased the soil porosity, infiltration rate, water retention and aggregate stability and not only reducing the bulk density but also maintained the temperature of the soil. Sahil hybrid exhibited maximum stem diameter and minimum stem diameter was found for both Anna and Sandal. Maximum increase in stem diameter revealed vigorous vegetative plant growth.

Also Aghdak P et al.,(2016) observed that peat moss media gave highest shoot fresh weight as compared to other media which might be due to the fact that peat moss growing media provide sufficient amount of nutrients and well balanced minerals. It has also been reported that peat moss media improved the vegetative growth parameter of the plant including plant height, shoot fresh weight and dry weight .and highest shoot dry weight in peat moss media, which may be due to the reason that peat moss medium is the rich source of all the basic nutrient i.e. nitrogen, phosphorus and potassium which helps in increasing the fertility of the growing media. They also stated that shoot dry weight was totally dependent on the vegetative growth of the plants.

Finally Council (2000) gives a very appropriate definition of compost, which is "Compost is the product resulting from the controlled biological decomposition of organic matter that has been sanitized through the generation of heat and stabilized to the point that it is beneficial to plant growth. It bears little physical resemblance to the raw material from which it has originated. It is an organic matter resource that has the unique ability to improve the chemical, physical, and biological characteristics of soils or growing media, and it contains plant 
nutrients but is typically not characterized as a fertilizer".

b- Effect of mineral N, P and $K$ :-

Sheykholeslamiet al., (2015) They investigated the effect of nitrogen fertilizer on the growth and essence yield of peppermint and announced that dry matter and essence yield was significantly increased when nitrogen fertilizer applied. Not only the nitrogen element does not exist into the essence compound, but also it is involved in the chemical compound of some molecules like Protein, amino acid and nucleic acid .The uses of this element causes increasing extraction gland of essence at the leaves of peppermint It is because of producing and consuming simple glucoses, increasing vegetative growth and developing leaves surface. The effect of chemical fertilizer as 90- 80-80 and then 90-50-80 on the some measured properties like plant height, the number of chains, leaves, stem and total wet weight, stem and total dry weight are more than other chemical fertilizer treatments, statistically; which is because of high nitrogen and potassium content at these types of chemical fertilizers. some quantitative characteristics like total wet and dry weight and also the content of essence of peppermint increased significantly using high $\mathrm{N}$ and $\mathrm{K}$ content compared to the low content ones.

\section{Conclusion}

The previously mentioned results concerning N,P and. $\mathrm{K}$ percentages in the dried herb showed that, inoculating the growing media with Sand+ peat moss+ compost improved $\mathrm{N}, \mathrm{P}$ and $\mathrm{K} \%$ in the dried herb and Vegetative and root growth with NPK fertilization at $6 \mathrm{~g} / \mathrm{pot}$ On the other hand, the least values in this respect was obtained by media with Sand with zero NPK fertilization in both growing seasons.

\section{Reference}

Aghdak P Mobli M \&Khoshgoftarmanesh AH (2016).Effect of different growing media on vegetative and reproductive growth of bell pepper. J Plant Nutr 39(7): 967- 973.

Composting Council. 2000. Field Guide to Compost Use.

Gamal Ahmed Ali Mostafa(2018) Effect of planting media and fertilization on growth and chemical composition of areca plant. M. Sc. Thesis, Fac. Agric., Benha Univ., Egypt.

Haidar, M. A. S. (2010): Effect of chemical fertilization and growing media on vegetative growth and chemical composition of two Cultivars of Dracaena marginata. M.Sc. Thesis, Fac. Agric., Cairo Univ., Egypt, 148pp.

Haidar, M. A. S. (2010): Effect of chemical fertilization and growing media on vegetative growth and chemical composition of two
Cultivars of Dracaena marginata. M.Sc. Thesis, Fac. Agric., Cairo Univ., Egypt, 148pp.

Hartmann, H.T., D.E. Kester, F.T. Davies and R.L. Geneve, (2002): Plant Propagation Principles and Practices. Prentice Hall, Upper Saddle River, New Jersey, USA.702 pp.

Hassan Salehi (2013) Effects of Different Pot Mixtures on spathiphyllum (Spathiphyllumwallisii Regel) Growth and Development journal center European agriculture DOI: /10.5513/JCEA01/14.2.1242

Hegazey , N.E. (2014): Physiological studies on improving propagation of Conocarpus erectus plant. Ph.D. Thesis ,Fac. Agric. ,Benhauniv .,Egypt.

Lambers, H., F.S. Chapin and T.L. Pons, (2000): Plant Physiology Ecology. Springer - Verleg New Yourk.Inc., 540 pp.

Mazher, A. A. M.; N. G. Abd El-Aziz, and E.E. Habba (2010): Impact of different soil media on growth and chemical constituents of Jatrophacurca L. seedling grown under water regime. Journal of American Science, 6(8): 549556.

MehboobAlam, ZawarHussain, IzharUllah, Samiullah, Imran Ahmad, Muhammad Asif, Muhammad Azhar Shah, Syed Qaisar Ali Shah and JoharRaza Khan. (2019) Effect of growing media on rooting response of tomato (LycopersicumesculentumL.) stem cuttings. Pure and Applied Biology. Vol. 9, Issue 1, pp884-896.

Mehmood TM, Ahmad W, Ahmad KS, Shafi J, Shehzad MA \&Sarwar MA (2013). Comparative effect of different potting media on vegetative and reproductive growth of floral shower (Antirrhinum majus L.). J Plant Sci 1(3):104-11

Mohamed, Y.F.Y., (2018): Influence of different growing media and Kristalon chemical fertilizer on growth and chemical composition of Areca palm (DypsiscabadaeH. E. Moore) plant. Middle East Journal of Applied Sci., Vol. 08 , 43-56

Moran, R., (1982).Formulae for determination of achlorophyllous pigments extracted with $N, N$ dimethylformamide. Plant Physiol. 69, 13761381 .

Olosunde, O. M.; Olulana, O. J.; and S. Aleu (2017): Effects of container opacity and growing medium on growth and aesthetic quality of dumb cane (Dieffenbachia amoena). European International Journal of Science and Technology, 6(4): 18-25.

Ribeiro, H.M., A.M .Romero, H. Pereira; P. Borges, F. Cabral and E. Vaconcelos, (2007): Evaluation of a compost obtained from forestry wastes and solid phase of pig slurry as a substrate for seedlings production. Bioresource Technology, Vol.98, 3294-3297. 


\section{Snedecor, G.W. and W.G. Cochran,}

(1989).Statistical Methods.8th Ed. Iowa State

Univ. Press, Ames Iowa, USA.

SupawatcharaSinghatong(2017) Antioxidant and antimicrobial potential of Aspidistra elatior extracts. Scholars Research Library Der Pharmacia Lettre, 2017, 9 [5]:149-155
Z. Sheykholeslami, M. QasempourAlmdari, S. Qanbari and M. Akbarzadeh2(2015) Effect of Organic and Chemical Fertilizers on Yield and Yield Components of Peppermint (Menthapiperita L. AJEA, 6(4): 251-257, 2015; Article no.AJEA.2015.084 .

اجريت هذه الدراسه بقسم البساتين -كليه الزراعه بمشتهرجامعه بنها -خلال الفتره من يناير 2018حتى يناير 2019لدراسه بعض انواع

بيئات النمو المخنلفه وكذلك مستويات النسميد المختلفه علي نبات الاسبدسترا

1

--ادي استخدام البئيه المحتويه علي رمل+ بيتموس +كمبوست الي زياده النمو الخضرى والجذري للنبات علي مستوي الموسم الاول والتاني

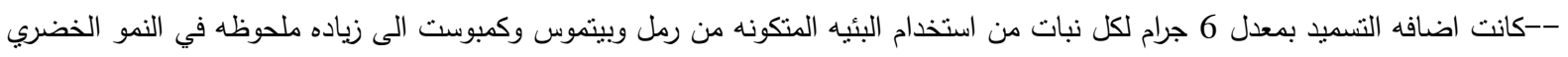

والجذري للموسمين الاول والتاني

2-المحتوى من الصبغيات النباتيه:

--ادي استخدام البئيه المحتويه علي رمل+ بيتموس +كمبوست الي زياده نسبه الكلورفيل (a/b) ) علي مستوي الموسم الاول والتاني --كانت اضافه التسميد بمعدل 6 جرام لكل نبات من استخدام البئيه المتكونه من رمل وبيتموس وكمبوست الى زياده نسبه الكلورفيل (a/b) ) اللموسمين الاول والتاني 3-المحتوبالكيماوى من العشب الجاف وسئ

ادي استخدام البئيه المحتويه علي رمل+ بيتموس +كمبوست الي زياده محتوي الاوراق من النتروجين والفوسفور والبوتاسيوم علي مستوي الموسم الاول والتاني

--كانت اضافه التسميد بمعدل 6 جرام لكل نبات من استخدام البئيه المتكونه من رمل وبيتموس وكمبوست الى لي زياده محتوي الاوراق من

$$
\text { النتروجين والفوسفور والبوتاسيوم علي مستوي الموسم الاول والتاني }
$$

التوصيه

يوصسباستخدام خليط البئيه المتكون من رمل وبيتموس وكمبوست مع اضافه التسميد بمعدل 6 جرام لكل نبات وذلك للحصول عل افضل نمو 